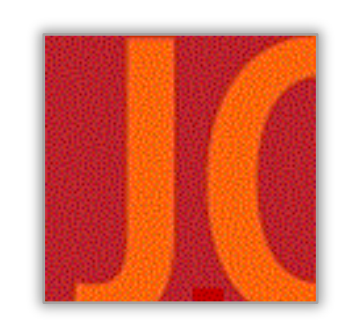

\title{
Now Has Always Been the Time
}

\author{
Ellyn Lyle, Yorkville University \\ Jodi Latremouille, Thompson Rivers University \\ \& David W. Jardine, University of Calgary
}

\begin{abstract}
:
Beginning from the assumption that we must learn to wonder as we wander, our writing here aims to advance theory and practice as they relate to walking. We understand walking as both an intentional physical activity and a curricular understanding of traversing with and through landscapes of topical relations in attunement with the Earth. We assume that insights gained through such attunement are accessed through deep consciousness of and presence with and, as such, we take up attunement in a variety of ways: spiritual (belonging in nature); intellectual (learning about relationships); physical (affecting the body); emotional (exploring love of nature); and imaginative (learning through creative engagement). Through critical, qualitative, creative, and arts-integrated approaches, we engage the praxis of living and being in relation.
\end{abstract}

Keywords: walking pedagogies; attunement; place-based inquiry; lived curriculum; currere 


\section{Maintenant a toujours été le moment}

\section{Résumé :}

Partant de l'hypothèse qu'il nous faut apprendre à nous émerveiller en flânant, notre écriture vise ici à faire progresser la théorie et la pratique en ce qui concerne la marche. Nous comprenons la marche à la fois comme une activité physique intentionnelle et comme une compréhension curriculaire de la traversée avec et à travers des paysages de relations d'actualité en harmonie avec la Terre. Nous supposons que les idées acquises grâce à une telle harmonisation sont accessibles par une conscience profonde et une présence avec et, en tant que tel, nous adoptons l'harmonisation de diverses manières : au spirituel (soit l'appartenance à la nature); à l'intellectuel (soit l'apprentissage des relations); au physique (affectant le corps); à l'émotionnel (par explorer l'amour de la nature); et l'imaginaire (l'apprentissage par l'engagement créatif). À travers des approches critiques, qualitatives, créatives et intégrées aux arts, nous engageons la praxis de vivre et d'être en relation.

Mots clés : pédagogies de la marche; harmonisation; enquête basée sur le lieu; curriculum vécu; currere 
It's an act of pretense which helps us survive, to feel there's ground under our feet, when we know full well that beneath that ground there is an eternity of stars and galaxies.

(Domanski, 2002, p. 249)

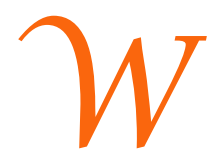

e often hear that we are living in extraordinary times. This gives us pause as we wonder, has there ever been a time that was not extraordinary? Even as we acknowledge some of the unique experiences that make our time remarkable, we feel our focus shifting away from the immediacies of contemporary distraction and exhaustion and panic toward a newlyemerging consciousness of and presence with.

And yet, as the writing that follows in this special issue will attest, this new emergence as well as the resistances to it, are also age-old and myriad and variegated:

As a weak person may die of thirst

While being carried away by a great river,

So the Dharma is ineffective unless meditated upon. (Namgyal, 2006, p. 9)

In our construed and constructed rushabouts, we are too often instructed that this is no time to be interrupting the well-oiled machinations of the dominant educative discourse. With increasing regularity, we are chastised for time spent in thinking, wondering, or wandering old Sainte Terre, feeling the deep ecological sorrows that surround us and feel, too, the crackling uprising of life when one stops being simply carried away. Namgyal (2006) also says, in urgent words that sound completely contemporary, that "some say the present age is not the time for meditation" (p. 5). He lived from 1511-1587.

But now is the time. Just as now has always been the time.

Being physically and spiritually attuned to the world around us forms the loom on which we weave our curricular understandings, and each weave is new, and each weave is ancient, all at once. Here, individually and collectively, we strive to find the extraordinary in the ordinary and make room for an integrated way of attending to the lived curriculum. More than an approach to doing research, we regard this way of being as a deep and disciplined presence with/in the world we inhabit. It is a way to inhabit classrooms as well, to teach, to learn. It is a way, therefore, to make the Earth, everywhere and always, a locale of pedagogical assembly and hospitality.

Accepting that we are visitors in the places we wander has helped us to "walk in a good way" (Tait, 2016, p. 21), treading lightly within the curriculum as terrain. Perhaps walking in a good way, after practice and study and breath, lets us finally and properly start to move away from the chaos that prevents conscious and responsible being. Perhaps, in the intimacies of breath and bone, we are what those adored places have helped us become. We are-we hope to be-becoming of these earthly locales and can sense the eternity of galaxies and stars.

Contemporary skitter-scatter stacks the odds against us. This is nothing new, although it always feels it. But the cyclical history of these not-really-new-at-all matters of walking and 
attunement and the lessons of generous and beautiful and difficult things help give gravity. It encourages the slow-down and sinking into those intimacies on behalf of teachers and students and schools and curricula. And then, on behalf of our own sanity, our health, our hale, our holy, are all tripped up together in old etymological reminders. A good thread to keep tied around our fingers.

Calling up from some distant tree, just audible, the eternity of galaxies and stars, right there, right here, this rock, that heat from the sun's arc. Simple, really, and the most difficult thing in the world as well.

Through our own individual practices of walking the earth, we invite exploration of the relationships between flesh and earth and breath, science and soul, past and present. There is a tougher glint here, too, in these relationships, as the places we occupy have often been occupied, propertied, re-named, scourged, killed off. This cannot be ignored. We are not talking simply of a nice walk in the park or stroll on the beach, because the park's enclosure hides the dates and times and places and colonizing impulses that have wrought it. We are also not talking simply of "getting out into" (some imaginary, romanticized image of) "untouched nature", as an escape away from some other place. These places, too, need walking, need our devoted care and consciousness, and the healing that such walking with attunement can provide us. But make no mistake - this is not an easy sojourn. Sometimes statues simply need to be torn down, place-wounds need painful lancing, names need re/naming. Sometimes that is the enactment needed to start clearing the air and opening ears and hearts. Through writing together-this collection really does feel written together and, we hope, reads that way too- we invite and incite difficult and necessary conversations for change.

Walking: Attuning to an Earthly Curriculum is a call to a participatory, practical, spiritual, sensory, and theoretical curriculum experience, within a field of places and relations. Within this special issue, and with each other, we ask, how we might imagine our curriculum topics as territories to be traversed carefully and thoughtfully and lovingly, in tune with environmental consciousness and human conscientiousness? We understand this meandering pursuit of critical consciousness as an intimate reciprocity (Abram, 1997) made possible through a resonant attunement with the Earth. Feinberg (2016) writes of a walking-based pedagogy that sees curriculum as "lived and emerging, somatic and contextual, personal yet political, and enhanced by curiosity and listening" (p. 150). Being attentive to the world in this way fosters curiosity regarding the ways our walking might resonate, attune, align, or dwell with the rhythms of the earth. Beginning from the assumption that we must learn to wonder as we wander, this collection brings together scholars who aim to raise awareness of our human being on this planet and, in so doing, attunement is taken up in a variety of ways: spiritual (belonging in nature); intellectual (learning about relationships); physical (affecting the body); emotional (exploring love of nature); and imaginative (learning through creative engagement). Through critical, qualitative, creative, and arts-integrated approaches, we engage the praxis of living and being in relation. 


\section{References}

Abram, D. (1997). The spell of the sensuous: Perception and language in a more-than-human world. Vintage Books.

Domanski, D. (2002). The wisdom of falling. An interview with S. D. Johnson. In T. Bowling (Ed.), Where the words come from: Canadian poets in conversation (pp. 244-255). Nightwood.

Feinberg, P. P. (2016). Towards a walking-based pedagogy. Journal of the Canadian Association for Curriculum Studies, 14(1), 147-165. https://jcacs.journals.yorku.ca/index.php/jcacs/article /download/40312/36186

Namgyal, D. T. (2006). Mahamudra-The moonlight-Quintessence of mind and meditation (L. P. Lhalungpa, Ed. \& Trans.). Wisdom. (Composed in the $16^{\text {th }}$ century)

Tait, L. (2016). A scattered people. In J. Latremouille, A. Bell, M. Krahn, Z. Kasamali, L. Tait, \& D. Donald (Authors), kistikwânihk êsko kitêhk: Storying holistic understandings in education. Journal of the Canadian Association for Curriculum Studies, 14(1), 8-22. https://jcacs.journals. yorku.ca/index.php/jcacs/article/view/40294/36182

Williams, T. T. (2012). When women were birds: Fifty-four variations on voice. Varrar, Straus \& Giroux. 